\title{
Crystallization of megacrysts from kimberlites: Geochemical evidence from high-Cr megacrysts in the Jericho kimberlite
}

\author{
M. G. Kopylova ${ }^{1}$, G. M. Nowell ${ }^{2}$, D. G. Pearson ${ }^{2}$ and G. Markovic ${ }^{1}$ \\ ${ }^{I}$ University of British Columbia, Dept. of Earth and Ocean Sciences, 6339 Stores Road, Vancouver, BC, Canada \\ 2 Durham University, Science Labs, Department of Earth Sciences, Durham DH1 3LE UK
}

\begin{abstract}
Megacrysts in the Jericho kimberlite occur as single discrete grains, intergrown grains of the same or different megacryst minerals, composite samples consisting of coarse megacrysts with interstitial finegrained domains, or fine-grained mosaic garnetites. Ten studied megacryst samples consist of pyrope, sodic diopside, forsterite, enstatite and ilmenite-geikelite. The megacrysts belong to two distinct assemblages, ilmenite-bearing and ilmenite-free, which correspond to commonly recognized $\mathrm{Cr}$-rich and $\mathrm{Cr}$-poor megacryst suites. Pyrope and pyroxenes in ilmenitefree samples are richer in $\mathrm{Cr}$ than respective minerals in the ilmenite-bearing paragenesis (Fig. 1). The megacryst minerals formed at $\mathrm{T} \sim 1200^{\circ} \mathrm{C}$ and $\mathrm{P}=60-70$ $\mathrm{kb}$, in the upper part of the asthenosphere, where they occur together with pyroxenite xenoliths.
\end{abstract}

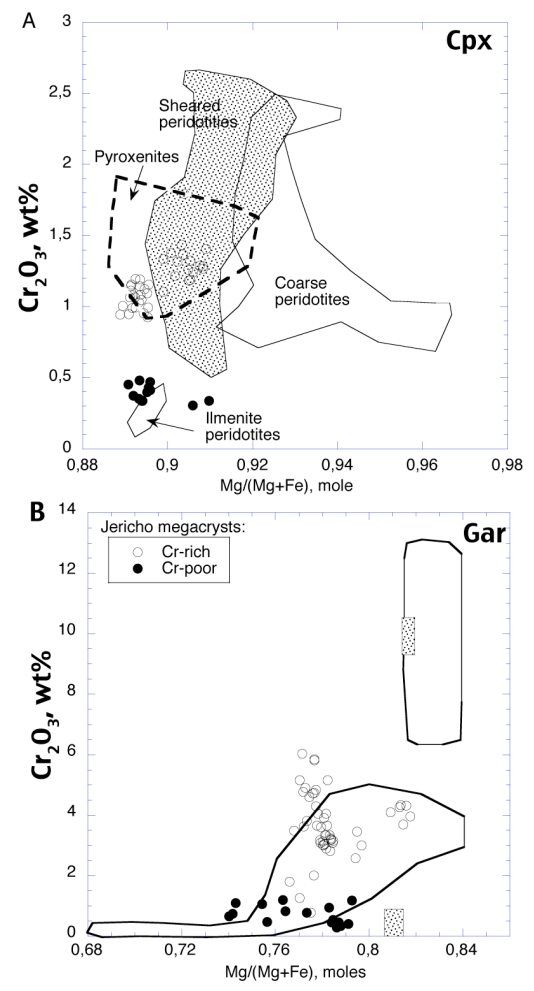

Fig. 1. $\mathrm{A} \mathrm{Cr}_{2} \mathrm{O}_{3}-\mathrm{Mg} /(\mathrm{Mg}+\mathrm{Fe})$ plot of clinopyroxene and garnet compositions in Jericho megacrysts. A: High-Cr and low-Cr clinopyroxenes in comparison with clinopyroxenes from various types of Jericho xenoliths (Kopylova et al., 1999). C: High-Cr and low-Cr garnets in comparison with other worldwide kimberlite locations containing both high-Cr and low-Cr megacrysts, i.e. State Line kimberlites (open fields, Eggler et al., 1979) and Veltevreden (filled fields, Moore and Belousova, 2005).
Coexisting garnet and clinopyroxene from the ilmenitefree, Cr-rich megacrysts were analysed for major and trace elements and $\mathrm{Sr}, \mathrm{Nd}$ and $\mathrm{Hf}$ isotopic compositions. Garnets show enriched and strongly fractionated REE patterns with the highest enrichment in HREE. Clinopyroxene REE patterns have "humped" shapes, with a positive slope for La-Pr and a negative slope for the rest of the rare earth elements. The Jericho megacrysts have REE patterns similar to that of other high-Cr megacryst suites and more strongly fractionated than low-Cr megacrysts (Fig. 2).

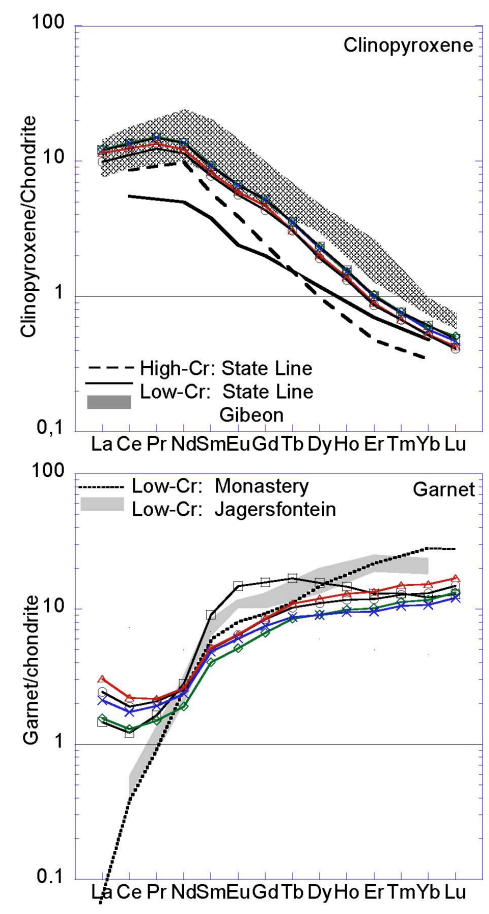

Fig. 2. Rare Earth Element patterns for Jericho Cr-rich megacrysts compared with literature data. i.e. clinopyroxenes from the State Line kimberlites (Eggler et al., 1979), low-Cr clinopyroxenes from the Gibeon province (Davies et al. 2001), low-Cr garnets from the Monastery mine (Jones 1987) and Jagersfontein (Burgess and Harte 2004).

Trace element patterns of melts equilibrated with the Jericho megacrysts were modeled based on recent experimental data on partitioning of trace elements between carbonate-rich melts and mantle minerals at high temperatures and pressures (Girnis et al., 2006; Keshav et al., 2005). Melts buffered by the Jericho megacrysts demonstrate highly fractionated patterns that decrease in abundances from 30-1000 times chondrite for highly incompatible elements to 2-5 times for heavy REEs. Melts buffered by megacrystal clinopyroxene are similar in REE composition to that 
of the host Jericho kimberlite, whereas melts equilibrated with garnet are less fractionated and resemble primitive Group I kimberlites from South Africa (Fig. 3). Previous modeling of melts equilibrated with megacrysts failed to produce REE patterns equivalent to kimberlitic melts and so concluded that the patterns are closer to those of the alkali basalt. Our modeling yields a very different result because 1) we based the modeling on high-Cr megacrysts that have steeper REE patterns, and 2) we used partition coefficients for carbonatitic highpressure and high-temperature melts (Girnis et al., 2006, Keshav et al., 2005).

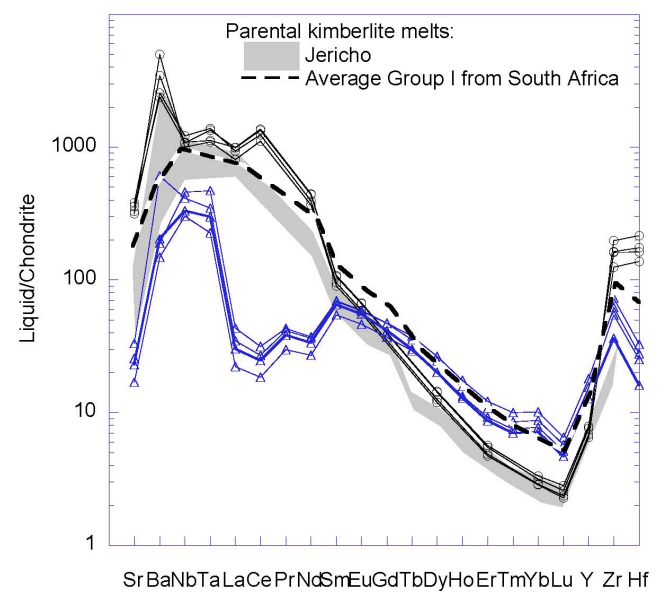

Fig. 3. Modelled trace element patterns for melts in equilibrium with Jericho megacrysts in comparison with that for parental kimberlite melts reconstructed for the Jericho kimberlite (Price et al., 2000) and Group I average South African kimberlite (Becker and Le Roex, 2006). Patterns with circles are for melts equilibrated with clinopyroxenes based on partition coefficients of Keshav et al., (2005) patterns with triangles are for melts equilibrated with garnets based on partition coefficients of Girnis et al. (2006).

Clinopyroxenes from the different garnetclinopyroxene pairs have rather homogenous initial $\varepsilon \mathrm{Nd}_{\mathrm{i}}$ values (3.0 to 3.4) whereas their initial $\mathrm{Hf}$ isotope compositions are much more variable $\left(\varepsilon \mathrm{Hf}_{\mathrm{i}} 6.1\right.$ to 13.0). Garnet initial isotopic compositions have a greater range for both $\mathrm{Nd}$ and $\mathrm{Hf}\left(\varepsilon \mathrm{Nd}_{\mathrm{i}}-4.5\right.$ to $3.4 ; \varepsilon \mathrm{Hf}_{\mathrm{i}}$ 5.1 to 9.2 ). Measured $\mathrm{Sr}$ isotope ratios in garnets are significantly more radiogenic $\left({ }^{87} \mathrm{Sr} /{ }^{86} \mathrm{Sr}\right.$ up to 0.71003$)$ than those of clinopyroxenes whereas initial ${ }^{87} \mathrm{Sr} /{ }^{86} \mathrm{Sr}$ values are fairly homogenous and unradiogenic $(0.702917$ to 0.70439 garnets and 0.703279 to 0.703377 clinopyroxenes). Three out of 5 bi-minerallic megacrysts show close agreement in the initial $\mathrm{Nd}$ isotope compositions of their garnet and clinopyroxene (within 0.3 epsilon units). Two of the megacrysts show significant initial $\mathrm{Nd}$ isotopic heterogeneity between garnet and clinopyroxene. The concordance between initial Hf isotope compositions of clinopyroxene and garnet at the time of kimberlite eruption is considerably worse than for $\mathrm{Nd}$, with 8 epsilon units difference between clinopyroxene and garnet. Bulk initial isotopic isotopic compositions for each bi-minerallic sample have been calculated from modal abundance estimates. Bulk initial isotope compositions show that the samples scatter around the mantle Hf-Nd isotope array, within the OIB field, with initial bulk $\varepsilon \mathrm{Nd}$ and $\varepsilon \mathrm{Hf}$ values to the radiogenic side of Bulk Earth. The high-Cr megacrysts largely overlap the compositional range of $\varepsilon N d$ shown by Jericho kimberlites (Dowall, 2004) but have consistently more radiogenic $\varepsilon H f$ than the kimberlites and plot closer to the mantle array (Fig. 4).

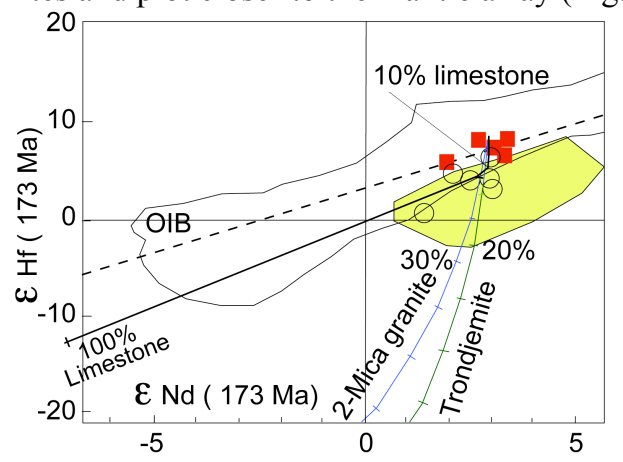

Fig. 4. Nd-Hf isotope compositions of Jericho megacrysts (red squares) compared with whole rock host kimberlite (open circles - Dowall, 2004). Compositions for crust endmembers from Dowall (2004), dashed line is the mantle array. A yellow field outlines compositions of low-Cr megacrysts from S. African kimberlites (Nowell et al., 2004)

Two-point isochrons can be calculated for each garnetclinopyroxene pair that should reflect the time since closure of the respective isotopic systems. $\mathrm{Rb}-\mathrm{Sr} 2-$ point isochrons for the Jericho megacrysts give a range of ages from $156.7+/-4.8 \mathrm{Ma}$ to $208.3+/-6.2 \mathrm{Ma}$, with 2 garnet-clinopyroxene pairs being within error of the eruption age of the host kimberlite $(172+/-2 \mathrm{Ma}$; Heaman et al. 1997). If all mineral pairs are regressed together, assuming crystallisation from a common parent magma, an $\mathrm{Rb}-\mathrm{Sr}$ errorchron of $179+/-21 \mathrm{Ma}$ results. Two-point Sm-Nd isochrons for megacryst pairs also scatter around the kimberlite emplacement age for 3 samples $(172+/-12$ Ma to $182+/-14 \mathrm{Ma})$ while 2 others are clearly aberrant $(45.6+/-6.6$ and 99 $+/-13 \mathrm{Ma})$. Regression of data for the 3 most concordant samples yield an isochron $(\mathrm{MSWD}=1.03$ ) of $177.0+/-7.3 \mathrm{Ma}$ (Fig. 5), within error of the kimberlite age. Exclusion of the 2 samples with

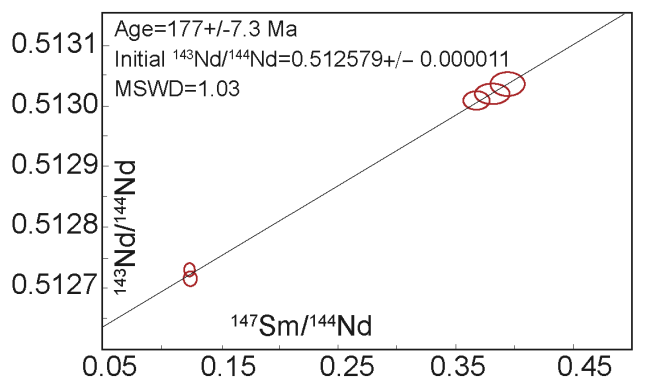

Fig. 5. Sm-Nd isochron for $3 \mathrm{Gt}-\mathrm{Cpx}$ biminerallic megacryst intergrowths from Jericho. Low $\mathrm{Sm} / \mathrm{Nd}$ points are clinopyroxene, high are garnet. Age uncertainty is 2-sigma.

aberrant ages can be justified on the grounds that these samples show by far the greatest degree of discordance in the initial $\mathrm{Nd}$ isotope ratios of their co-existing garnet and clinopyroxene. Two-point Lu-Hf isochrons are less consistent than the $\mathrm{Rb}-\mathrm{Sr}$ and $\mathrm{Sm}-\mathrm{Nd}$ systems. Regression of the same three samples used for the multi-point $\mathrm{Sm}-\mathrm{Nd}$ isochron yields an errorchron age 
$(\mathrm{MSWD}=11)$ of $169+/-63 \mathrm{Ma}$, close to the age of kimberlite eruption but with a large uncertainty. Increased scatter of the multi-point Lu-Hf ischron results from the greater degree of heterogeneity in initial Hf isotope ratios of all the megacrysts examined. Overall, the Rb-Sr, Sm-Nd and Lu-Hf isochron ages for the megacrysts are within error of the eruption age of the kimberlite, indicating isotopic closure during eruption.

The similarity in initial isotope ratios of the megacryst isochrons and host kimberlites makes it unlikely that the megacrysts are significantly older than the host kimberlites. As with low-Cr megacryst suites (e.g., Davies et al. 2001), the Jericho high-Cr megacrysts have considerably less radiogenic $\mathrm{Sr}$ than their host kimberlites and this has been taken to indicate a noncogenetic origin. However, the $\mathrm{Sr}$ isotopic range of Jericho kimberlites can be easily modelled by moderate degrees of contamination $(<5 \%$ to $10 \%)$ of local crust, such as limestone or granite, into a magma that had an initial $\mathrm{Sr}$ isotope composition similar to the megacrysts (Fig. 6). Limestone addition will affect Sr with very little effect on $\mathrm{Nd}$ or $\mathrm{Hf}$ isotope compositions.

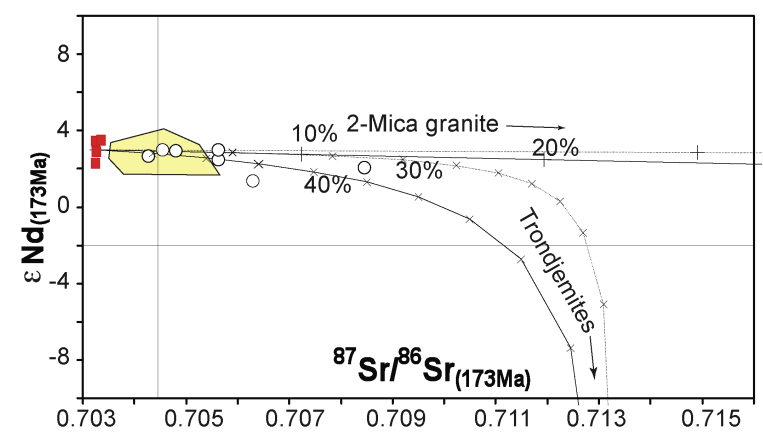

Fig. 6. Sr-Nd isotope compositions of Jericho megacrysts (red squares - calculated bulk compositions of the Cpx-Gt intergrowth) compared with whole rock host kimberlite (open circles - Dowall, 2004) and S. African megacrysts (yellow field, Nowell et al., 2004). Compositions for crust endmembers from Dowall (2004).

The less radiogenic Hf isotope compositions of the host kimberlites are also consistent with moderate crustal contamination, mostly likely from a granitic lithology (Fig. 4). Hence, the high-Cr Jericho megacryst intergrowths could have crystallized from the same parent magma that the host kimberlites evolved from, once the effects of crustal contamination are accounted for. This, together with the likelihood that the megacrysts formed at a similar time to the host kimberlite and equilibrated with kimberlite melt with respect to trace elements, suggests a strong genetic link between the two, with the megacrysts representing the early evolution of the kimberlite magma. The high-Cr compositions of the Jericho megacrysts along with their more radiogenic $\mathrm{Hf}$ isotope compositions compared with southern African low-Cr megacryst compositions (Fig. 4) could be related to more extensive interaction of the parent magma or fluid with incompatible-element depleted, high-Cr lithospheric peridotite at the base of the lithospheric mantle.

\section{References:}

Becker, M., and Le Roex, A.P., 2006. Geochemistry of South African on- and off-craton, Group I and Group II kimberlites: Petrogenesis and source region evolution: Journal of Petrology, v. 47, 673-703.

Burgess, S.R., and Harte, B., 2004. Tracing lithosphere evolution through the analysis of heterogeneous G9G10 garnets in peridotite xenoliths, II: REE chemistry: Journal of Petrology, v. 45, 609-634.

Davies, G.R., and Spriggs, A.J., 2001. A non-cognate origin for the Gibeon kimberlite megacryst suite, Namibia: Implications for the origin of Namibian kimberlites: Journal of Petrology, v. 42, 159-172.

Dowall, D.P., 2004. Elemental and isotopic geochemistry of kimberlites from the Lac de Gras field, Northwest Territories, Canada. PhD thesis, University of Durham.

Eggler, D.H., McCallum, M.E., Smith, C.B., 1979. Megacryst assemblages in kimberlite from Northern Colorado and Southern Wyoming: petrology, geothermometry-barometry, and areal distribution. The Mantle Sample. F. R. Boyd and O. A. Meyer. Washington, American Geophysical Union, 213-226.

Jones, R. A., 1987. Strontium and neodymium isotopic and tate earth element evidence for the genesis of megacrysts in kimberlites of southern Africa. Mantle Xenoliths. P. H. Nixon (Ed.). New York, John Wiley \& Sons Ltd: 711-724.

Heaman, L.M., Kjarsgaard, B.A., Creaser, R.A., Cookenboo, H.O. and Kretchmar, U., 1997. Multiple episodes of kimberlite magmatism in the Slave Province, North America. In:- LITHOPROBE report no 56, 14-17.

Keshav, S., Corgne, A., Gudfinnsson, G.H., Bizimis, M., McDonough, W.F., and Fei, Y.W., 2005. Kimberlite petrogenesis: Insights from clinopyroxene-melt partitioning experiments at $6 \mathrm{GPa}$ in the $\mathrm{CaO}-\mathrm{MgO}$ $\mathrm{Al}_{2} \mathrm{O}_{3}-\mathrm{SiO}_{2}-\mathrm{CO}_{2}$ system: Geochimica et Cosmochimica Acta, v. 69, 2829-2845.

Kopylova, M.G., Russell, J.K., and Cookenboo, H., 1999. Petrology of peridotite and pyroxenite xenoliths from the Jericho kimberlite: Implications for the thermal state of the mantle beneath the Slave craton, Northern Canada: Journal of Petrology, v. 40, 79-104.

Girnis, A.V., Bulatov, V.K., Lahaye, Y., and Brey, G.P., 2006. Partitioning of trace elements between carbonate-silicate melts and mantle minerals: Experiment and petrological consequences: Petrology, v. 14, 492-514.

Moore, A., and Belousova, E., 2005, Crystallization of $\mathrm{Cr}$ poor and $\mathrm{Cr}$-rich megacryst suites from the host kimberlite magma: implications for mantle structure and the generation of kimberlite magmas: Contributions to Mineralogy and Petrology, v. 149, 462-481.

Nowell, G. M., Pearson, D. G., Bell, D.R., Carlson, R.W., Smith, C. B., Kempton, P.D. and Noble, S.R., 2004. Hf isotope systematics of kimberlites and their megacrysts: New constraints on their source region. J. Petrology, 45, 1583-1612.

Price, S.E., Russell, J.K., and Kopylova, M.G., 2000. Primitive magma from the Jericho Pipe, NWT, Canada: Constraints on primary kimberlite melt chemistry: Journal of Petrology, v. 41, 789-808. 
